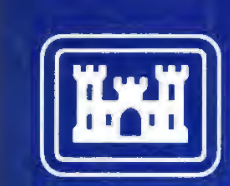

US Army Corps of Engineers

\title{
SIDE-SCAN SONAR INVESTIGATION OF BREAKWATERS AT CALUMET AND BURNS HARBORS ON SOUTHERN LAKE MICHIGAN
}

by

\author{
Andrew Morang \\ Coastal Engineering Research Center \\ DEPARTMENT OF THE ARMY \\ Waterways Experiment Station, Corps of Engineers \\ PO Box 631, Vicksburg, Mississippi 39180-0631
}
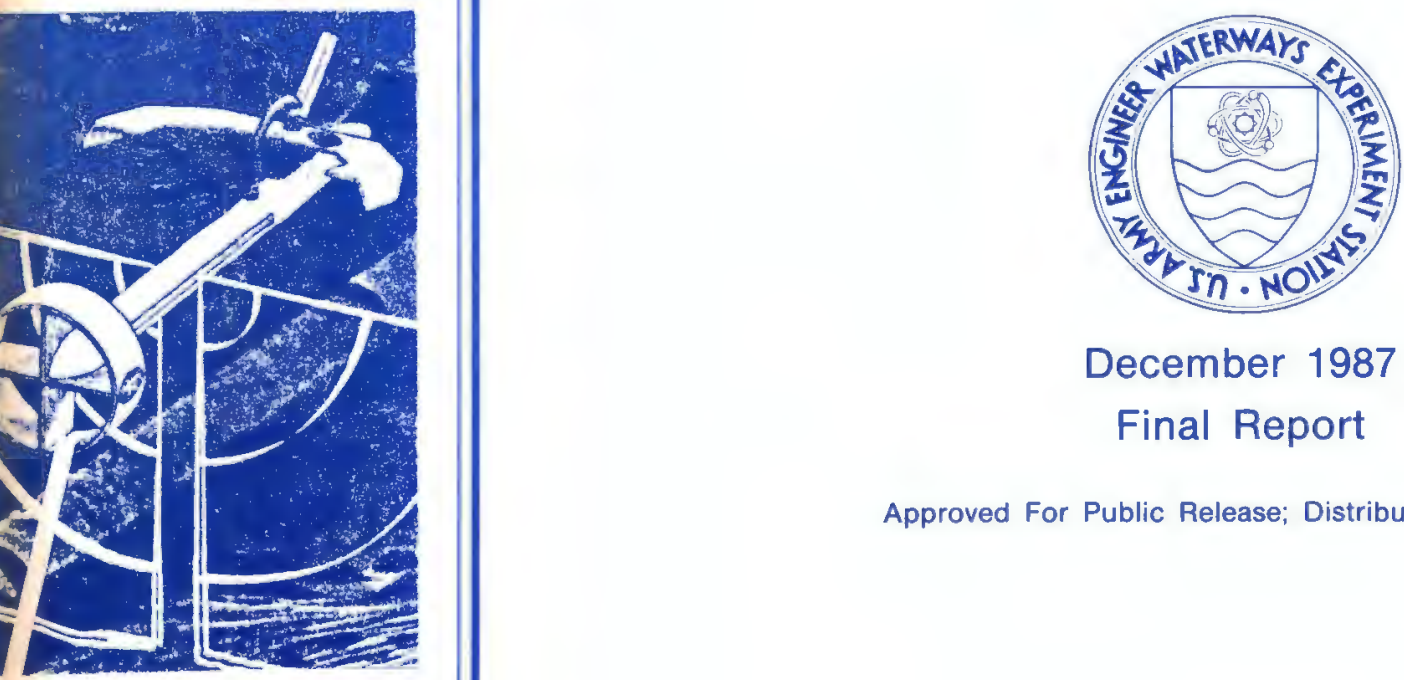

December 1987

Final Report

Approved For Public Release; Distribution Unlimited

Prepared for US Army Engineer District, Chicago 219 South Dearborn Street Chicago, Illinois 60604-1797 
When this report is no longer needed return it to the originator.

The findings in this report are not to be construed as an official Department of the Army position unless so designated by other authorized documents.

The contents of this report are not to be used for advertising, publication, or promotional purposes. Citation of trade names does not constitute an official endorsement or approval of the use of such commercial products. 
Unclassified

SECURITY CLASSIFICATION OF THS PAGE

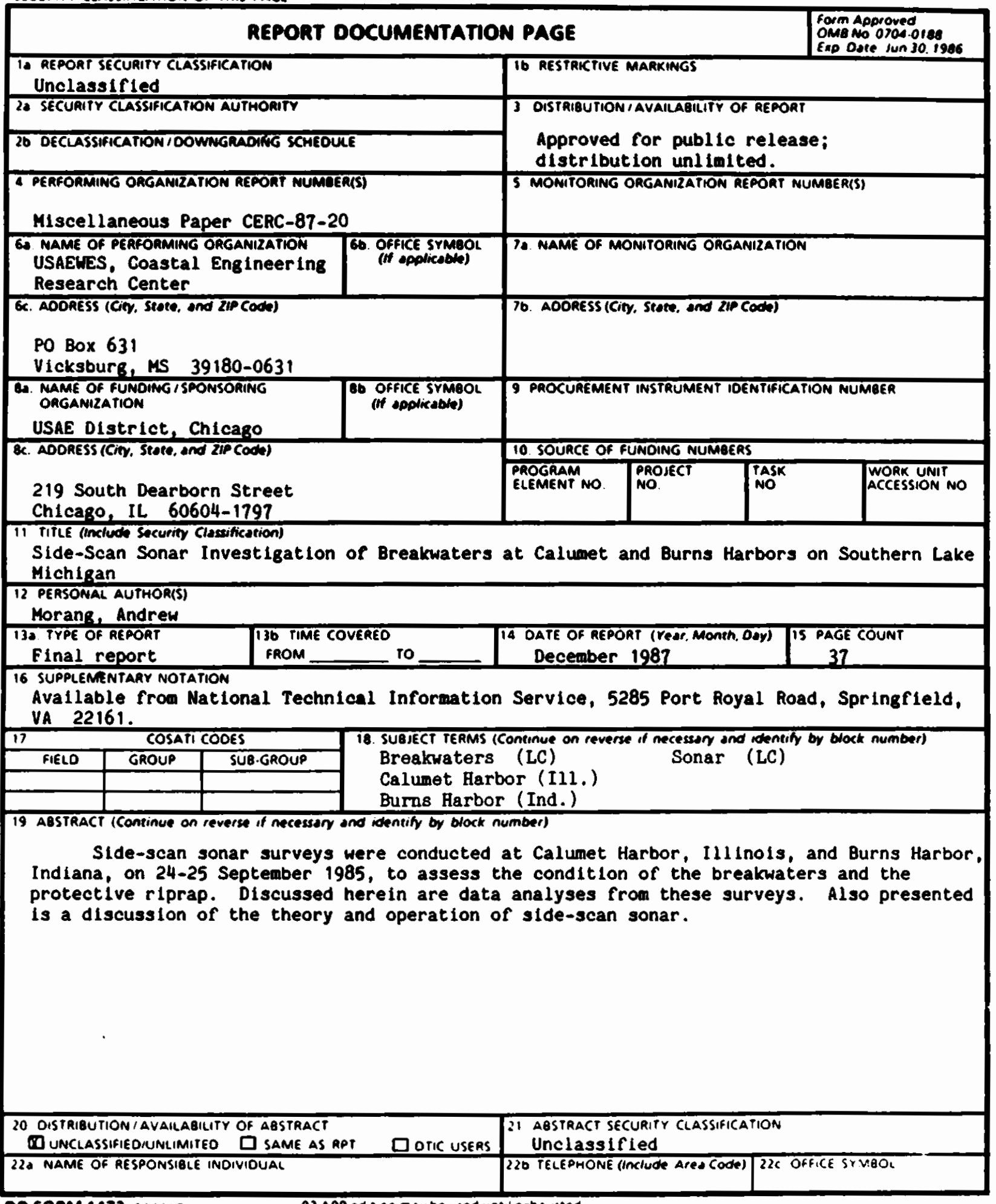


Unclassifled

SECUATY CLASSIRTCATION OF TAIS PACE

Unclassifled

SECURTY CLASSIFICATION OF TMIS DACE 


\section{PREFACE}

This report was prepared by the US Army Engineer Waterways Experiment Station's (WES's) Coastal Engineering Research Center (CERC) for the US Army Engineer District, Chicago (NCC), to support studies of the proposed rehabilitation of the breakwaters at Calumet Harbor, Illinois, and Burns Harbor, Indiana.

Messrs. Andrew Morang, Physical Scientist, and William M. Kucharski, Equipment Specialist, Prototype Measurement and Analysis Branch (CD-P), Engineering Development Division (CD), CERC, conducted the survey with assistance from NCC personnel. The survey at Calumet Harbor was performed on $24 \mathrm{Sep}-$ tember 1985 and at Burns Harbor on 25 September 1985 from SB David Boyd by Messrs. Preston B. Russell, Gordon Brown, Melvin E. Simpson, and Earl D. Tompkins, NCC, whose sk111 and cooperation helped ensure high quality data acquisition. Personnel from NCC instrumental in the establishment of this study included Messrs. Harry Krampitz, Chief, Hydraulic and Environmental Engineering Branch, and Gerald J. Stadler, Chief, Project Management Branch.

This report was prepared by Mr. Morang under direct supervision of Dr. Dennis R. Smith, former Chief, CD-P, and Mr. Thomas W. Richardson, Chief, $C D$; and under general supervision of Mr. Charles C. Calhoun, Jr., Assistant Chief, and Dr. James R. Houston, Chief, CERC. The author wishes to thank Mr. Michael J. Hemsley, CD-P, and Ms. Joan Pope, Chief, Coastal Structures and Evaluation Branch, for making suggestions and reviewing the manuscript. This report was edited by Ms. Shirley A. J. Hanshaw, Information Products Division, Information Technology Laboratory, WES.

During report publication, Commander and Director of WES was COL Dwayne G. Lee, CE. Technical Director was Dr. Robert $W$. Whal in. 


\section{CONTENTS}

\section{PREFACE.}

CONVERSION FACTORS, NON-SI TO SI (METRIC) UNITS OF MEASUREMENT........ 3

PART I: $\quad$ INTRODUCTION................................... 4

PART II: SIDE-SCAN SONAR THEORY AND OPERATION................... 6

PART III: DATA ANALYSIS FOR CALUMET HARBOR..................... g

Breakwater Section A................................... 11

Breakwater Section B................................... 13

Breakwater Section $C . \ldots \ldots \ldots \ldots \ldots \ldots \ldots \ldots \ldots \ldots \ldots \ldots \ldots, 17$

PART IV: DATA ANALYSIS FOR BURNS HARBOR..................... 22

Harbor Side............................................ 22

Lakeside......................................... 22

PART V: $\quad$ SUMMARY........................................ 29

REFERENCES......................................... 30

TABLES $1-3$ 


\section{CONVERSION FACTORS, NON-SI TO SI (METRIC)}

UNITS OF MEASUREMENT

Non-SI units of measurement used in this report can be converted to SI (metric) units as follows:

Multiply

feet

knots (international)

miles (US statute)

pounds (mass)

tons $(2,000$ pounds, mass)

$\frac{B y}{0.3048}$
0.5144444
1.609347
0.4535924
907.1847

To Obtain metres

metres per second

kilometres

kilograms

kilograms 


\section{SIDE-SCAN SONAR INVESTIGATION OF BREAKWATERS}

AT CALUMET AND BURNS HARBORS ON

SOUTHERN LAKE MICHIGAN

\section{PART I: INTRODUCTION}

1. On 24-25 September 1985, the US Army Engineer Waterways Experiment Station Coastal Engineering Research Center (CERC) performed side-scan sonar surveys of the breakwaters at Calumet Harbor, Illinols, and Burns Harbor, Indiana, both located along the southern shore of Lake Michigan (Figure 1*). Purposes of the surveys were to assess the condition of the breakwaters, examine the condition and continuity of protective riprap, and study adjoining harbor and lake floors. This project was conducted as part of the US Army Engineer District, Chicago's (NCC's), ongoing engineering studies in preparation for rehabilitation of the breakwaters.

2. This report is organized into three sections: a general description of the operation and theory of side-scan sonar, results of the survey at Calumet Harbor, and results at Burns Harbor.

* A table of factors for converting non-SI units of measurement to SI (metric) units is presented on page 3. 


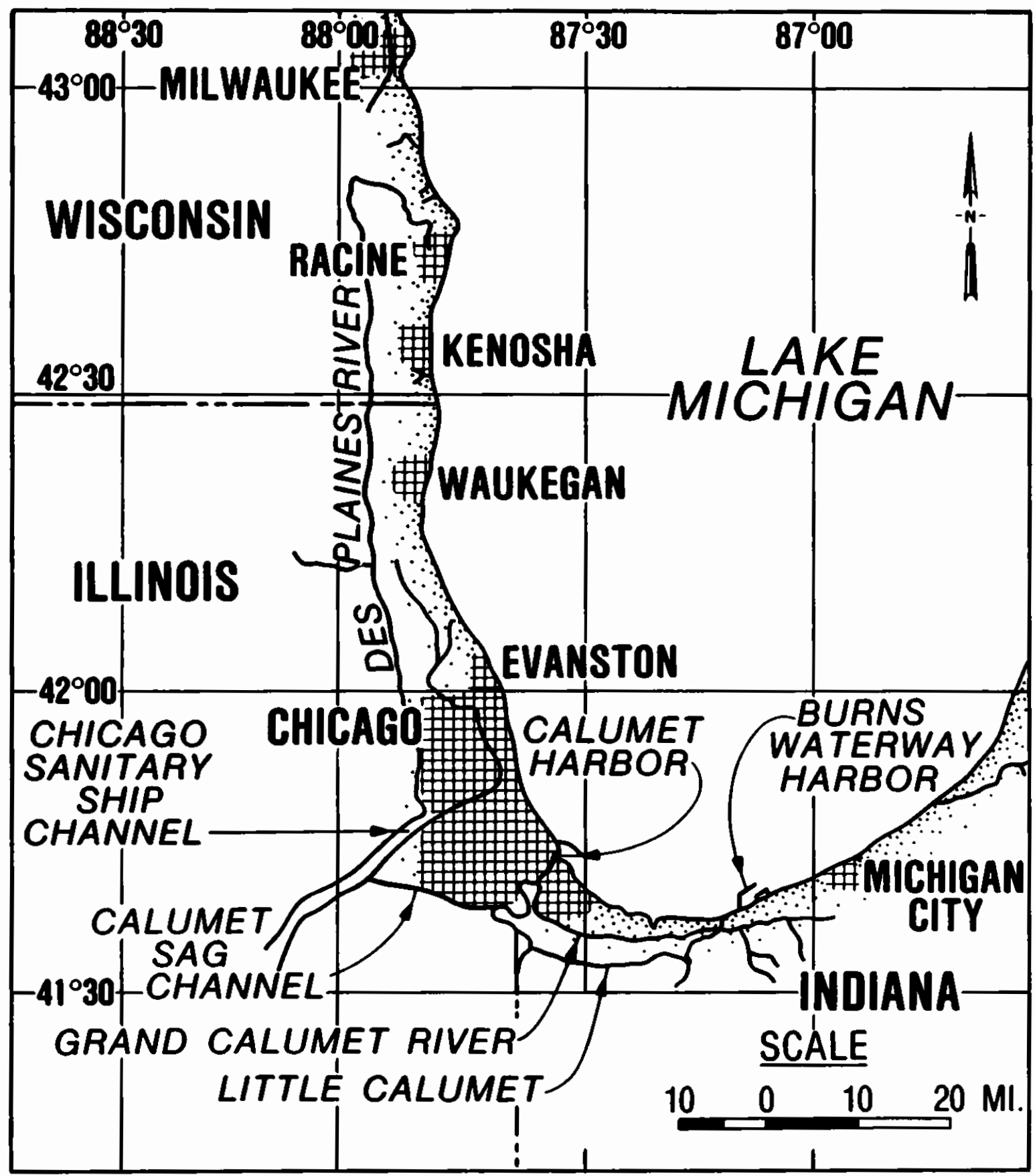

Figure 1. Area map of southern Lake Michigan with Calumet and Burns Harbors along the southern shore 


\section{PART II: SIDE-SCAN SONAR THEORY AND OPERATION}

3. Side-scan sonar is a system of imaging underwater objects using high-frequency acoustic signals. Originally developed during World War II to detect enemy submarines, commercial systems designed for scientific use became available in the 1960's and since then have been extensively used by oceanographic institutions, universities, pipeline and marine construction companies, archaeologists, and treasure-hunters. CERC's long association with various types of seismic systems has involved examination of Civil War era dams, waterways, and breakwaters (W1lllams (1982), Patterson and Pope (1983), Pope (1985), and Clausner (in press)).

4. The basic side-scan system consists of three parts: (a) the transducers, mounted in a hydrodynamically streamlined body (towfish), towed by the survey vessel at a depth below the turbulence of the propeller wash, (b) a graphic chart recorder combined with a signal transmitter and processor, and (c) a tow cable connecting the two units (Figure 2). Deployed a certain distance above the seafloor and lake floor, the towfish emits a pulse of sonar energy. This narrow pulse is transmitted at right angles to the towfish's tow direction and reflects from objects on the lake floor. Transducers in the towfish receive the reflections and send them to the signal processing system onboard the survey boat where they are recorded in analog form on paper strip charts. Each returning signal is plotted on the paper a distance from the center line corresponding to the time it was received. The center line on the analog record represents the towfish's trackline. Seafloor objects which are close to the trackline are displayed near the center line, while objects located close to the limit of the selected horizontal range are printed at the edges of the record. Objects directly underneath the towfish are not usually imaged because of the geometry of the sonar's beam pattern. The horizontal distance that is imaged can be selected by the operator and for most commercial side-scan sonars can be set between 25 and $500 \mathrm{~m}$. The cholce of hor 1zontal range is based on water depth, type of search pattern, size and shape of target, and desired resolution of the image. Usually a range of 25 to $50 \mathrm{~m}$ is selected when a detalled image is desired, while a general reconnaissance survey will be run at a range of $100 \mathrm{~m}$ or more.

5. The recorded image is called a sonograph and is analogous to a continuous aerial photograph. It can give indications of the nature of the 


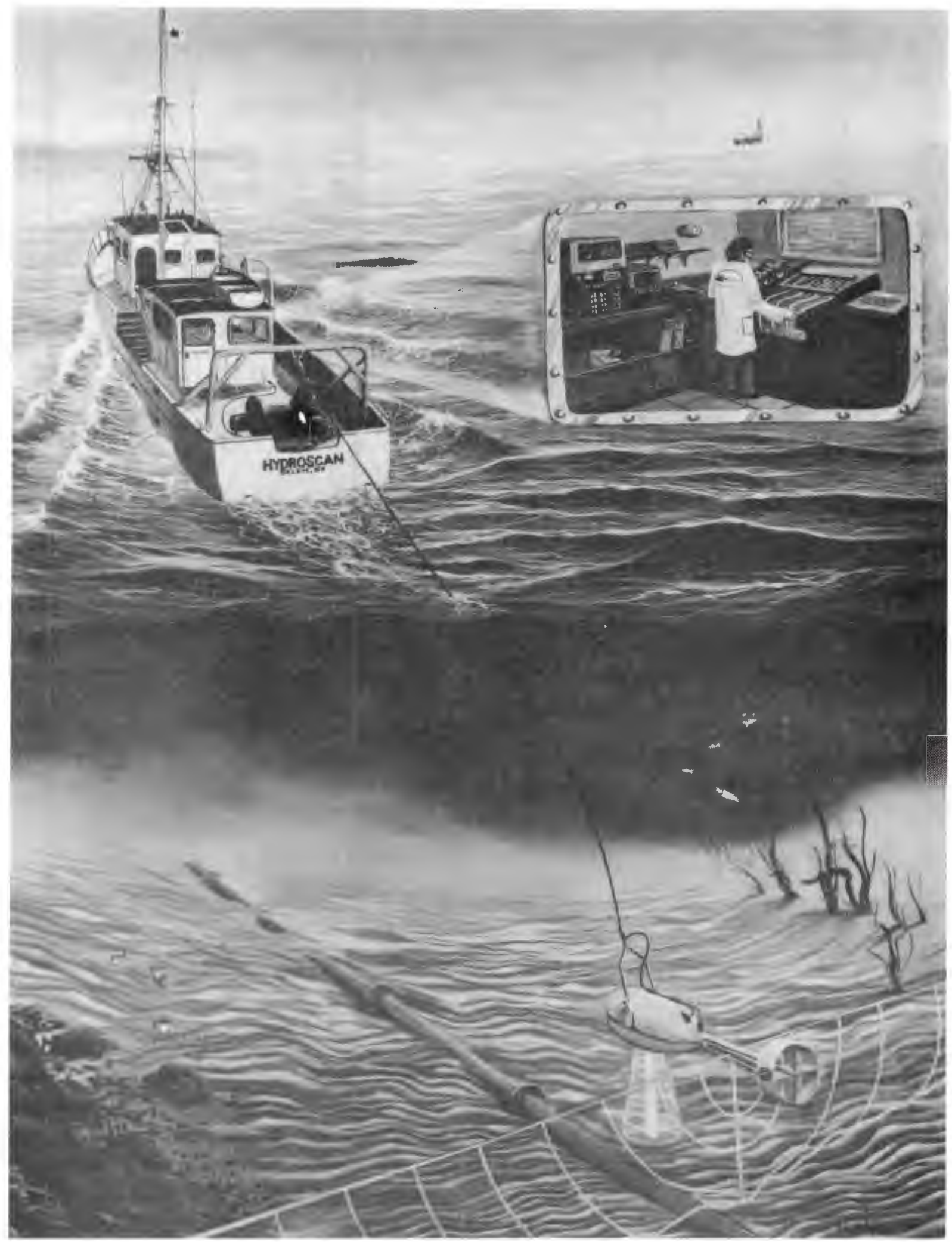

Figure 2. Components of a typical side-scan sonar system (Courtesy of Klein Associates, Inc.) 
reflecting surface since the stronger the returning signal the darker the corresponding mark on the paper. The intensity of a reflected signal is a function of material properties as well as of relief. Hard objects such as boulders or steel debris will produce an intense reflection; whereas a flat, clay seafloor will reflect very little of the signal. On most side-scan systems, the reflection of an object is recorded as black, and the acoustic shadow area behind is white. The width of this shadow zone and position of the object relative to the towfish can be used to calculate the object's height. Flemming (1976), Belderson, et al. (1972), Mazel (1985), and Leenhardt (1974) provide additional details on the use of and theory behind side-scan sonar.

6. The system used on this project was an EG \& G Model 260 image correcting side-scan sonar. Signal processing capabilities of the unit allowed it to provide sonar images which were fully corrected for slant range, ship speed, and amplitude with resulting records showing an accurate plan view of lake floor physical features. The survey was run using a 100-kHz transducer in the towfish at 25- and 50-m ranges and at survey speeds of 2 to 3 knots. Positioning was accomplished by observing the passage of 100-ft station fixes painted on the breakwater and by manually triggering the event marker on the side-scan system at every fifth station. Triggering was delayed long enough for the sonar towfish to be directly adjacent to the station with horizontal position error estimated at $\pm 5 \mathrm{~m}$. Survey conditions during both days were excellent, with waves less than $0.5 \mathrm{~m}$ high. 


\section{PART III: DATA ANALYSIS FOR CALUMET HARBOR}

7. Sections A, B, and C of the Calumet Harbor breakwater were surveyed on 24 September (Figure 3) at horizontal range scales of 25 and $50 \mathrm{~m}$. Sections $A$ and $B$ consist of wooden cribs (Figure 4) which were built on land by skilled carpenters, floated into place, and filled with stone rubble. This breakwater was completed in 1904, a concrete cap was added in the 1920's, and toe armor was added at various times.

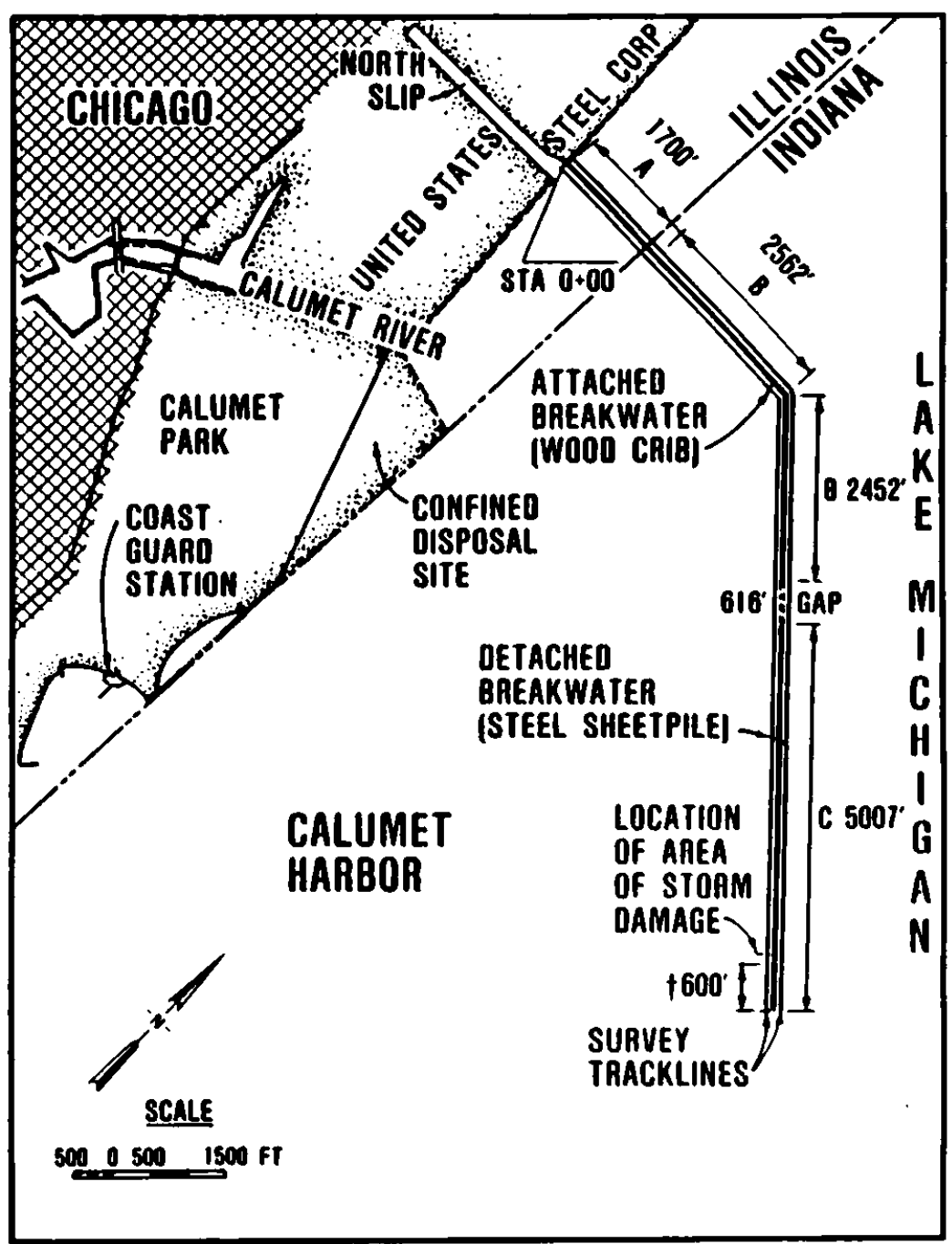

Eigure 3. Survey locations at Calumet Harbor, 24 September 


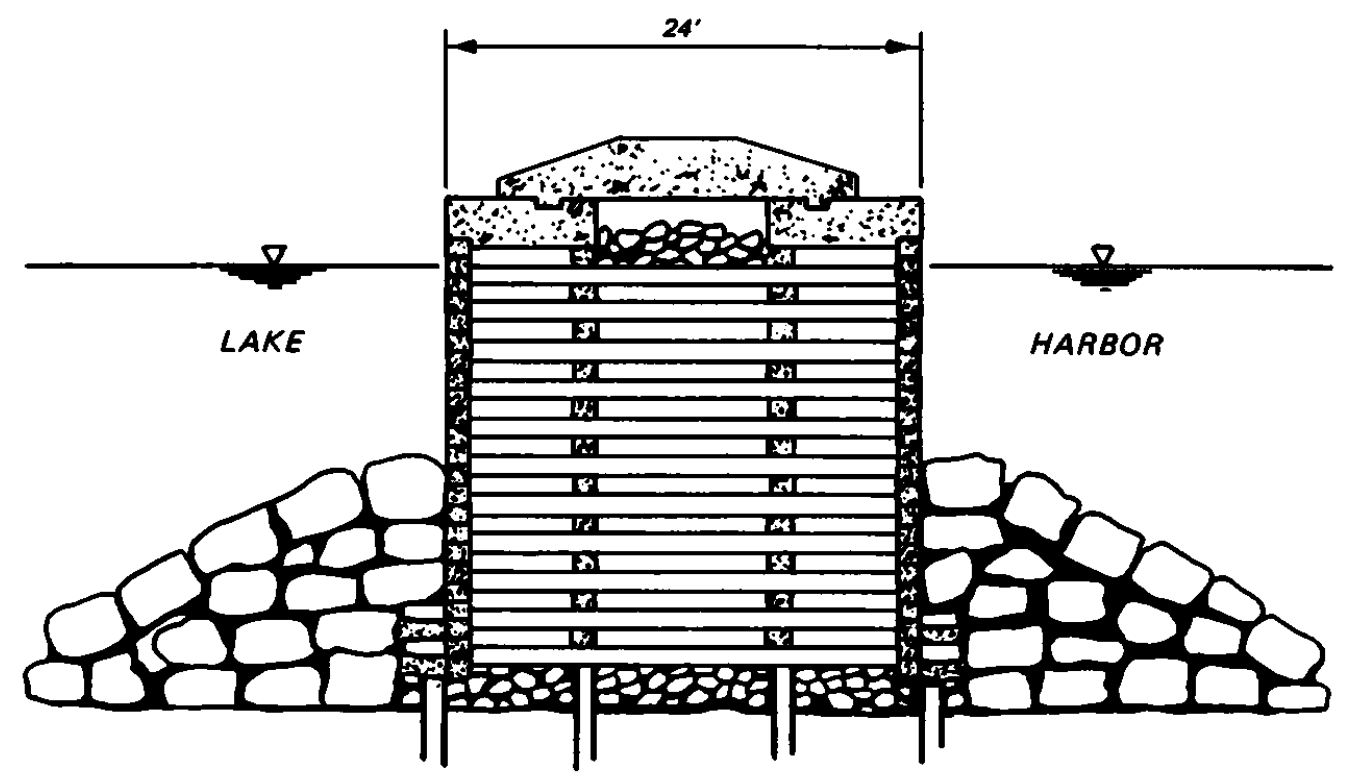

SECTION A

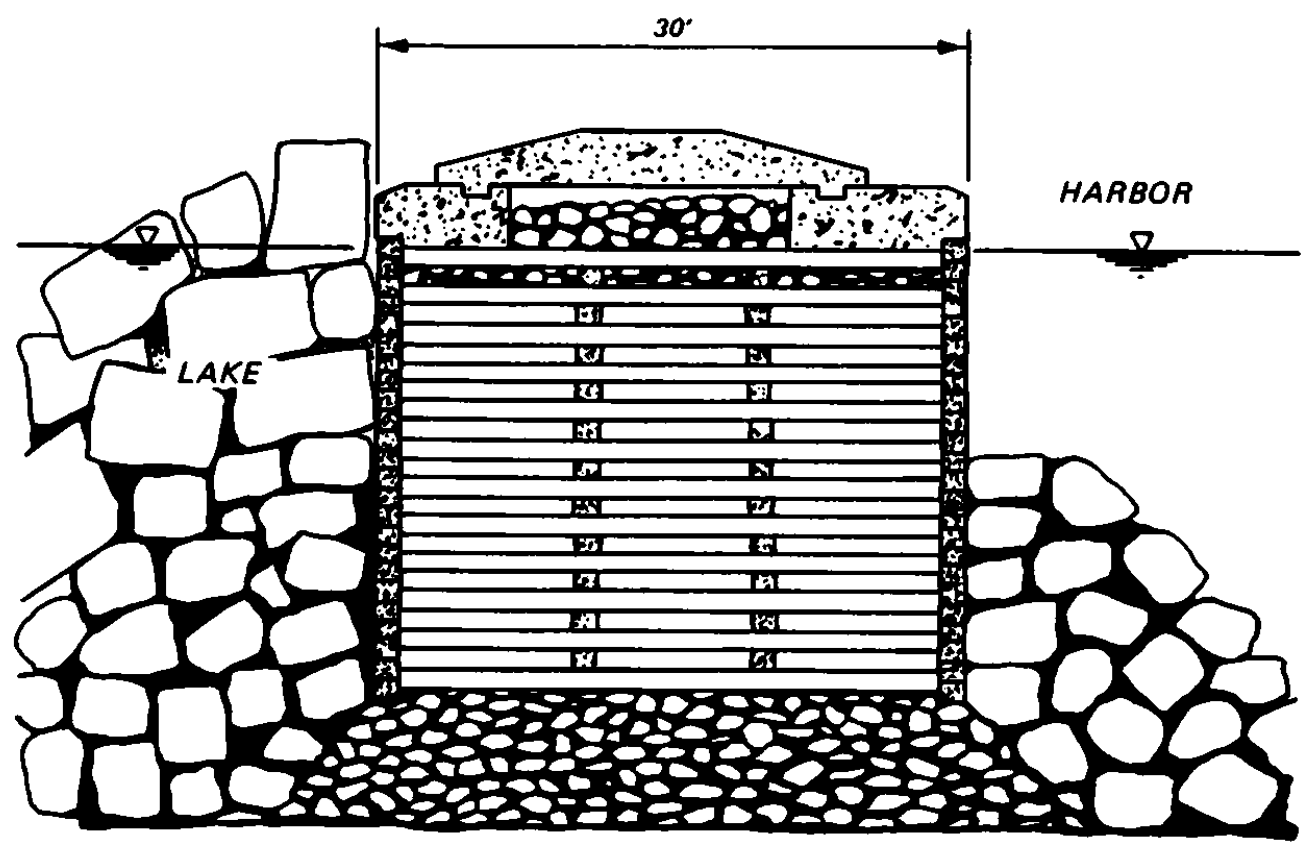

SECTION B

Figure 4. Wooden cribs forming Sections $A$ and $B$ of the Calumet Harbor attached breakwater 


\section{Breakwater Section A}

Harbor side

8. Protective stone at the toe extends continuously along Section $A$ varying in width from 7 to $10 \mathrm{~m}$ between sta $0+00$ and 3+00 but then increasing in width to about $15 \mathrm{~m}$. From sta $12+00$ eastward to the end of $A$, the toe stone is ragged and discontinuous and may consist of coarse stone deposited during repair activity. The harbor floor in this region is a featureless, low- to medium-reflectivity material, probably clay.

9. Most of the exposed face of the wood cribs appears to be intact along the harbor side of Section A. An exception occurs near sta 15+00 where a section of the crib has been displaced inward (northward toward the lake) less than $0.5 \mathrm{~m}$. The side-scan sonar records obtained on the lakeside of the breakwater reveal more clearly that this crib unit is out of alignment, but it is not possible to determine if it has broken or has tilted in one piece. Lakeside

10. The toe of Section $A$ is protected by an armor stone berm which varies in width from 13 to $20 \mathrm{~m}$. At sta 10+00, a lobe of the armor extends up to $30 \mathrm{~m}$ out from the toe of the cribs and may be coarse stone deposited recently for protective or repair purposes. The lake floor in this area is featureless and of low reflectivity, probably clay.

11. The lakeward face of the Section $A$ breakwater is discontinuous and irregular, and numerous individual cribs project outward from the main body of the breakwater (Figure 5). Displaced units occur near sta $4+00,8+00,9+00$, $12+00$, and 15+00. The unit at sta 15+00 has been noted earlier in conjunction with a displacement evident on the harbor side. Numerous irregular reflections occur up to $3 \mathrm{~m}$ behind the face of the breakwater, and it is hypothesized that they occur at gaps in the damaged face of the cribs where the acoustic signal has entered a void and has reflected from the fill material within the cribs. These void reflections occur near sta $4+00$ and $6+00$ through 10+00, 12+00, and 13+00 (Figure 5). In support of this hypothesis, these reflections do not occur on the harbor side of Section $A$ where the physical environment is less severe and where the faces of the cribs appear to be in better condition. 


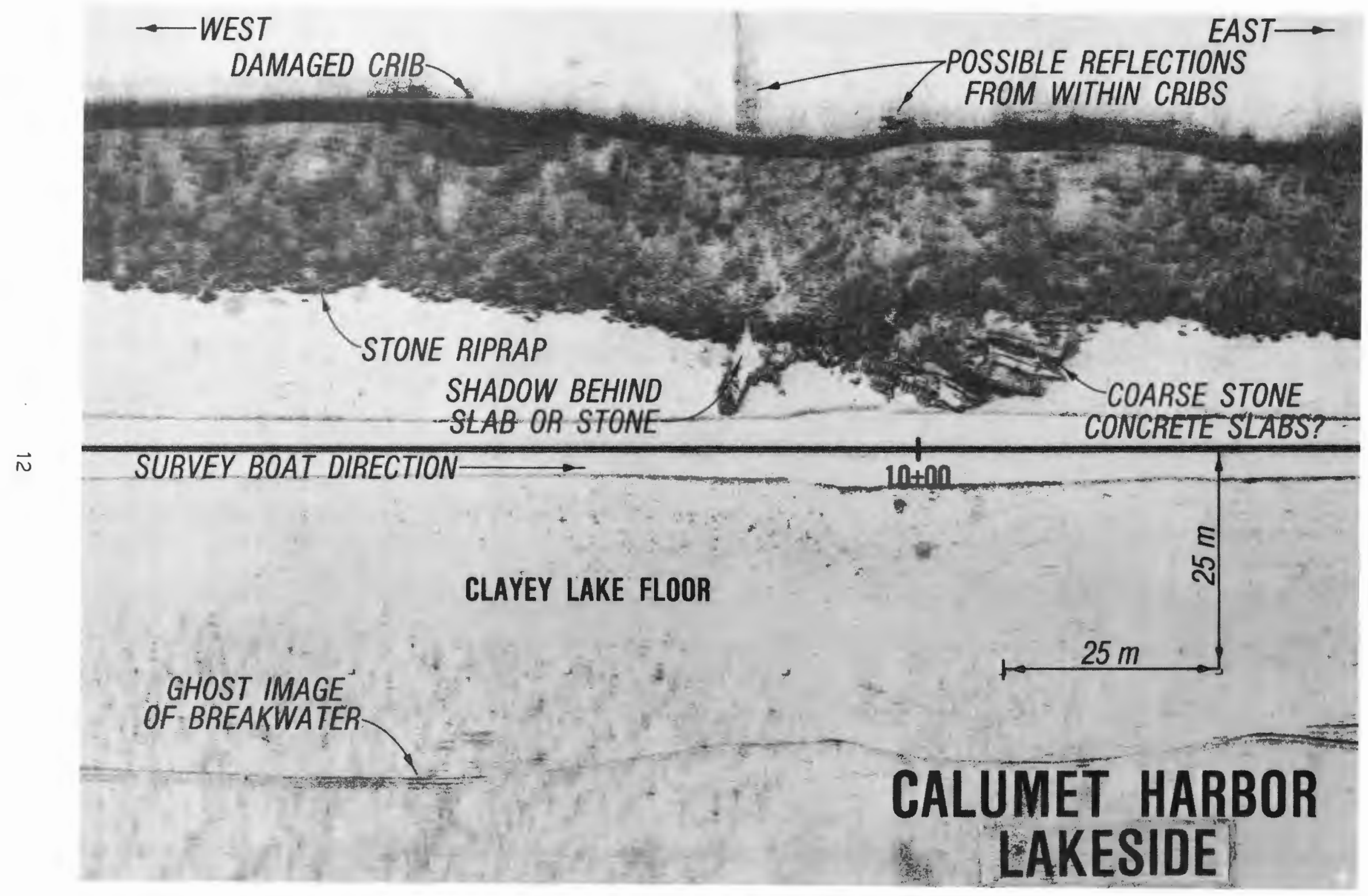

Figure 5. Lakeside, Section A, Calumet Harbor breakwater 


\section{Breakwater Section B}

\section{Harbor side}

12. The harbor-side section of the Calumet Harbor attached breakwater consists of 10-m-wide wood cribs capped with a concrete superstructure and protected with a stone riprap toe. Side-scan sonar records reveal that the riprap is not continuous along the harbor side of Section B and is entirely missing or perhaps buried in some areas. Table 1 summarizes the condition.

13. Several areas where the wood cribs may have been damaged are suggested by the records. The most prominent example occurs near sta $35+00$ where a section is apparently leaning outward or lying on the harbor floor. Similar linear reflections nearby, along the toe, may represent other broken crib fragments on the harbor floor. Near sta $35+00$, several zones of indistinct reflections occur behind the face of the breakwater. As explained earlier, these are believed to be reflections from the interiors of damaged cribs. Less distinct reflections of the same nature occur near sta $46+00$ and $49+00$. Between sta $48+00$ and $52+00$, several fan-shaped deposits of stone and gravel extend up to $14 \mathrm{~m}$ out from the base of the breakwater. These may be debris cones of fill that have flowed out from gaps in damaged cribs. This analysis is corroborated by the Calumet Harbor Reconnaissance Report (NCC 1985) which states that there are voids in some of the cribs in this area. Two other debris cones occur just east of the bend near sta $42+00$.

14. The harbor floor along most of section B consists of lowreflectivity clay with occasional textured, coarser areas. Irregular, highlyreflective patches which occur along the toe of the breakwater may represent sand or gravel accumulations. The 25-m-range records reveal that numerous individual stones appear on the bottom up to 50 to $60 \mathrm{~m}$ away from the breakwater. The records become darker as the end of Section $B$ is approached, suggesting an increasing sand content on the harbor floor. The floor within the gap itself is primarily sandy, and dramatic, large wavelength sand waves occur just to the south of the lighthouse.

Lakeside

15. The data from this side of the breakwater reveal two significant features: (a) The presence of large fields of sand waves and ripples suggests that the physical environment is at times severe; and (b) the protective riprap toe at the base of the breakwater is more continuous, wider, and more substantial than that on the harbor side. 
16. The riprap which extends continuously along Section B is 12 to $15 \mathrm{~m}$ wide. Between sta $23+00$ and $28+00$, a deposit of finer stone extends out onto the lake floor up to $32 \mathrm{~m}$ from the edge of the breakwater. Although the size of this deposit appears to be too great to be the result of debris that has flowed out of damaged cribs, the Calumet Harbor Reconnaissance Report (NCC 1985) indicates that some of the units in this area are probably damaged since they have a steep lakeward slope. Alternatively, the report states that protective stone was placed along this area during 1961-62. Possibly some of this material was relatively fine and flowed out onto the lake floor under the influence of waves or was substandard in size and discarded by the contractor. A similar but smaller deposit of fine stone occurs near sta $31+00$ to $32+00$, and an oval patch $15 \mathrm{~m}$ in diameter occurs near sta 34+00, $30 \mathrm{~m}$ from the breakwater. More oval patches, consisting of somewhat coarser material, can be seen between sta $54+00$ and $57+00$ (Figure 6 ) as far as $35 \mathrm{~m}$ from the breakwater. Among these coarse oval patches is is a prominent pile (near the center of Figure 6) with relief of $2 \mathrm{~m}$ (based on a geometrical reconstruction using the height of the towfish and the horizontal dimensions). Possibly, these are dredged material disposal mounds placed during maintenance operations. Particularly large armor blocks are at the base of the breakwater between sta $38+00$ and the bend. An occasional individual block on the lake floor in this area probably represents more material dropped during construction. Numerous individual large stones are also on the lake floor off the southern tip of Section B. Coarse stone riprap prevents imaging the cribs directly, but the crest can be marked by parallel black lines in Figure 6 .

17. The lake floor consists of clay close to shore and becomes sandy lakeward of sta $30+00$. Sand waves and ripples with various orientations and wavelengths can be seen throughout the area. East of the breakwater between sta 43+00 and 50+00 the lake floor has a granular appearance and may be partially covered with gravel or fine stone. Mottled patches of clay are evident on the floor of the gap south of Section B, and it is likely that in this area there is a discontinuous veneer of sand over an essentially clay bottom. Most sediment movement probably occurs during winter storms when waves along the southern shoreline of Lake Michigan can exceed $4 \mathrm{~m}$. Significant wave heights of 4 to $5 \mathrm{~m}$ were measured outside of Burns Harbor, Indiana, in February 1987 (Figure 7) using tripod-mounted, pressure-sensing wave gages located $30 \mathrm{~m}$ offshore from the breakwater on the lake floor. These data were collected and 


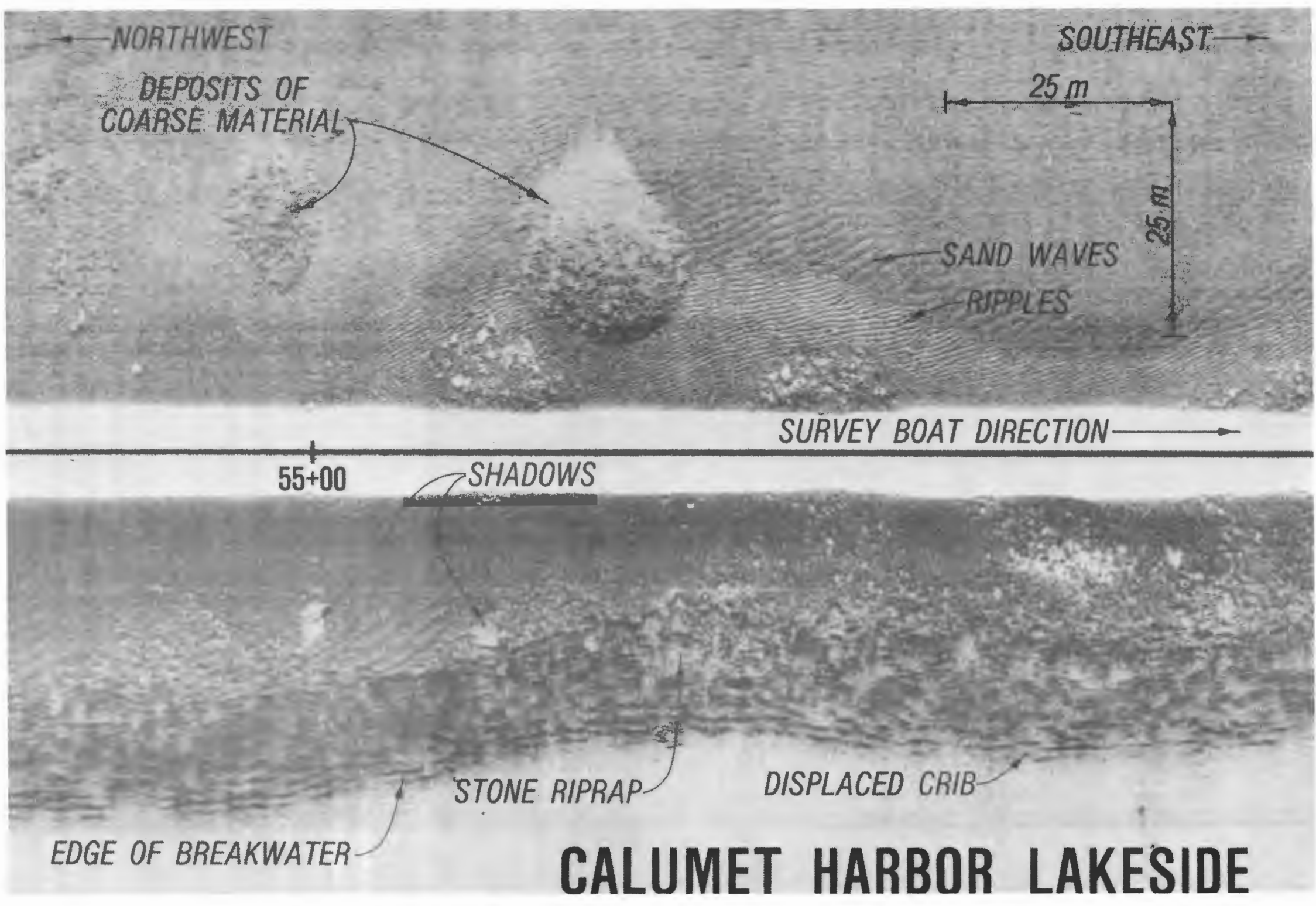

Figure 6. Lakeside, Section B, Calumet Harbor breakwater 


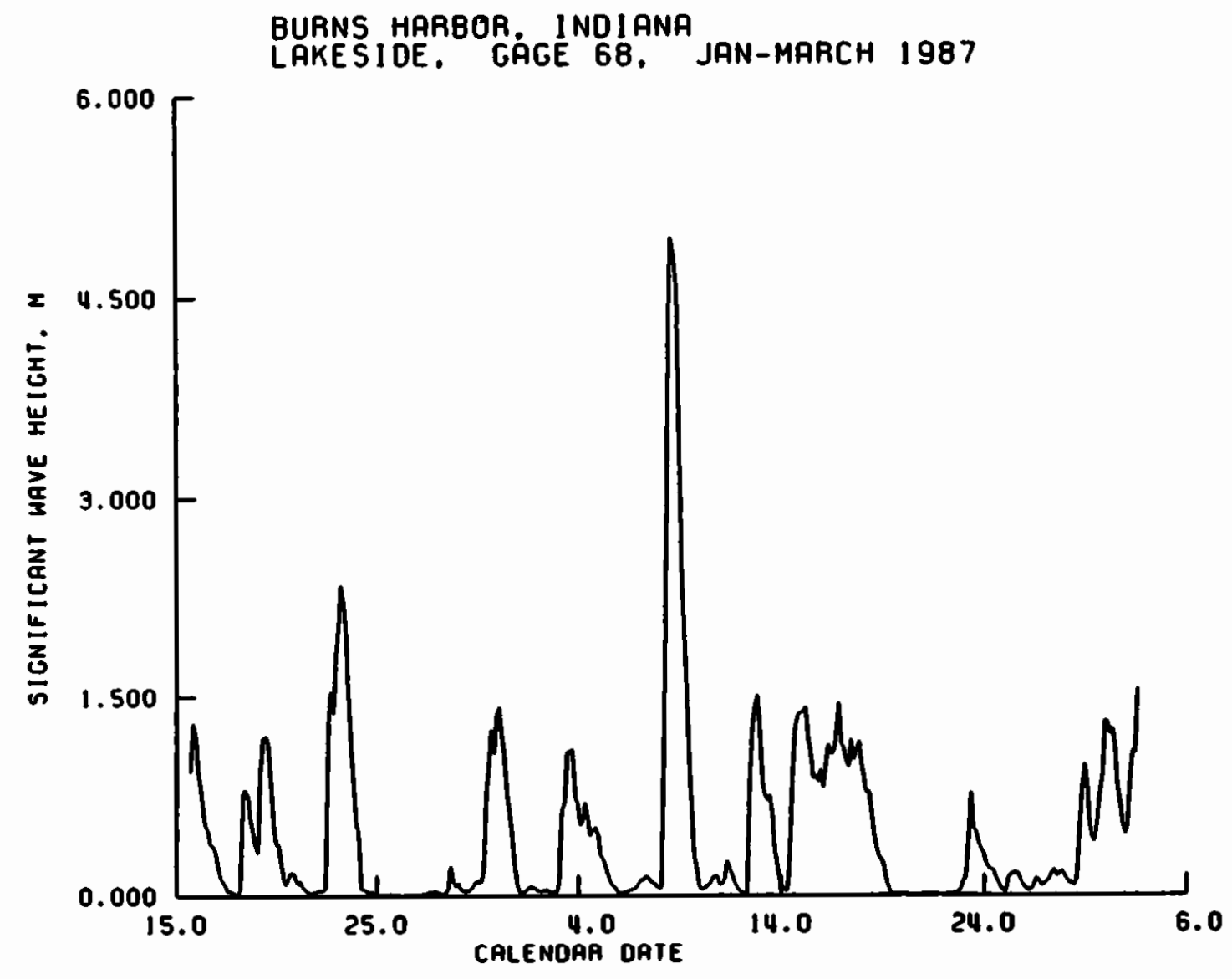

Figure 7. Plot of significant wave heights during January to March 1987, at Burns Harbor, Indlana

processed by the Prototype Measurement and Analysis Branch, CERC.

18. Because the armor protection extends from the lake floor nearly to the water surface, the wood cribs could not be imaged during this part of the survey, and it has not been possible to directly assess their condition. From sta $15+00$ to near $60+00$, the breakwater is marked by two or three heavy black lines on the side-scan sonar records (Figure 6). The water lake surface was high during the survey, and the lines may represent the platform and the beveled edge of the concrete cap which lies on top of the cribs. The lines are not continuous, and numerous minor displacements suggest that many of the cribs may be tilting. If the walls of the cribs have spread apart, some of the timbers which should be flush with the edge of the cap might be exposed and could be causing the heavy black lines on the records. 


\section{Breakwater Section C}

Harbor side

19. The Calumet Harbor detached breakwater constructed in 1935 is composed of 131 stone-filled diaphragm sheet-pile cells (Figure 8). According to the Calumet Harbor Reconnalssance Report (NCC 1985), the piles were driven approximately 2 in into an essentially sandy lake floor, and project maps indicate that some areas were composed of hard limestone.

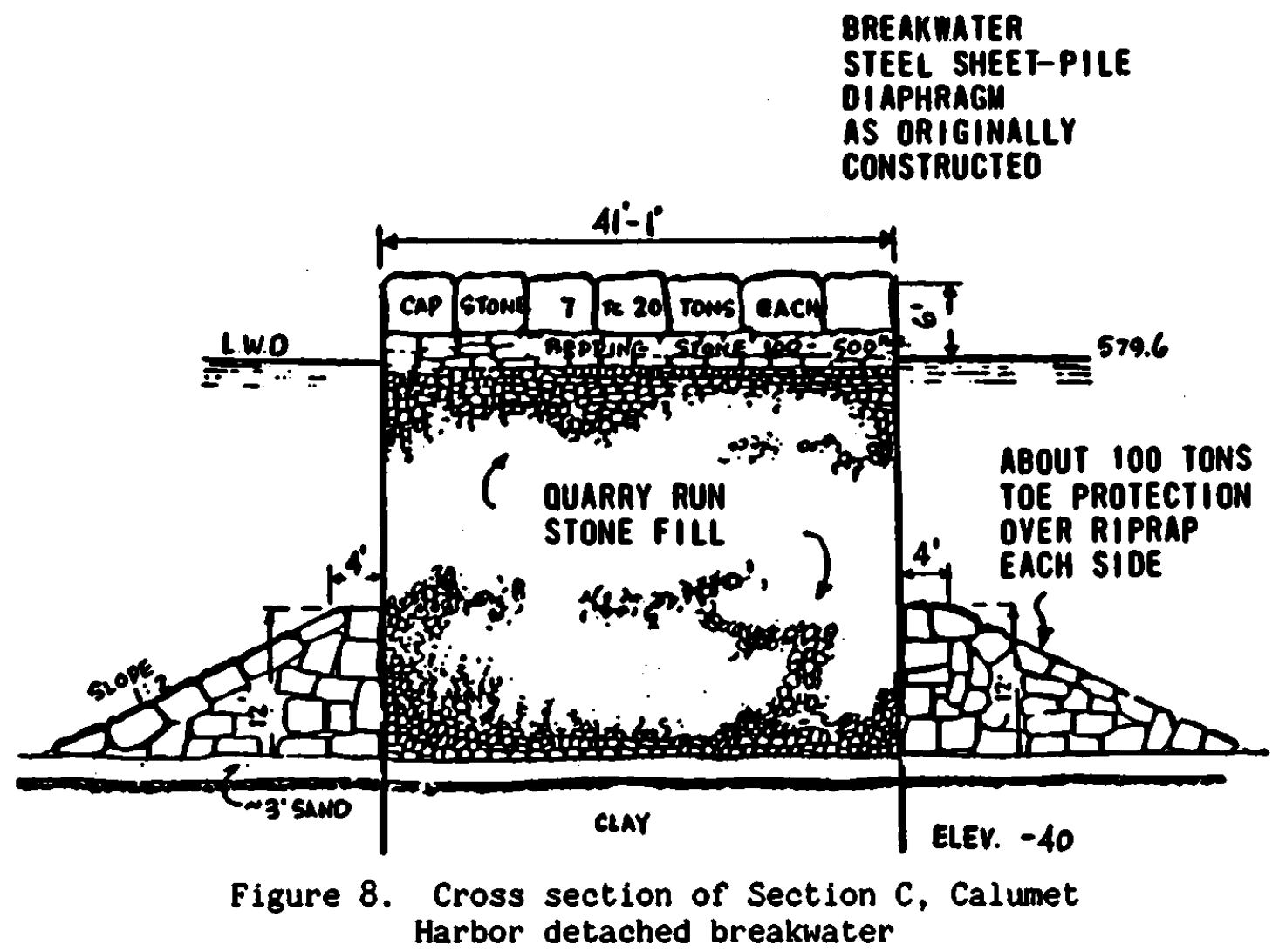

20. The side-scan sonar survey shows that the harbor floor along most of Section C is predominantly featureless and of low-reflectivity, probably clay. There is no evidence of sand waves or ripples, even near the breach where storm waves in 1984 destroyed two cells and where the wave regime should be more than energetic enough to move noncohesive sediments. Only at the far south end of the breakwater does the lake floor become darker (i.e. demonstrating higher reflectivity), and large fields of ripples can be seen in the records. Here, too, wave action may be moving accumulations of sand which may be spreading over some of the clayey harbor floor. 
21. Stone riprap toe extends along the entire breakwater. Between sta $79+00$ and $96+00$, occasional individual stones or small clusters of stone can be seen on the harbor floor near the toe. Some of these stones may have been displaced from the riprap by storm waves, or they may have been dropped during repair or construction of the breakwater. Table 2 summarizes the condition of the toe armor.

22. The rounded sheet-pile cells shown in the records (Figure 9) appear to be essentially in good condition. Because of the intensely strong signal return from the vertical steel walls, minor damage to the walls, such as gaps only a few centimeters wide, may be masked or not resolved. There is no signal penetration through the steel walls, and the faint lines and texture on the records are diffraction hyperbolae and noise. The breach where the cells failed in the 1984 storm is marked by an interruption in the sheet-pile cells and by debris on the harbor floor shown in Figure 9. The survey did not image within the actual breach itself because most of the signal reflected from the mounds of stone and debris.

Lakeside

23. The lakeside of the breakwater is exposed to a dynamic environment, as illustrated by the fields of ripples and sand waves in the sandy lake floor. Considerable coarse debris, similar to or larger than the riprap, is scattered about on the lake floor up to $35 \mathrm{~m}$ from the base of the breakwater. The high rellef of individual blocks is indicated by long shadows. Since it seems unlikely that large armor stones had been moved up to $35 \mathrm{~m}$ by storm waves, most of these deposits are probably the result of construction and repair activities. Some of the stones may have been displaced by ice. During winter storms, the spray from breaking waves mantles the breakwater and can build up ice incrustations a meter or more high. Breaking waves can conceivably strike the ice mounds with enough force to dislodge them along with underlying stones. Nevertheless, in southern Lake Michigan it is unlikely that the ice incrustations would be voluminous enough to provide flotation to the blocks, which would allow them to be carried away from the structure." Between sta $92+00$ and $100+00$, irregular oval patches of unidentified coarse material occur on the lake floor to at least $60 \mathrm{~m}$ from the breakwater (Figure 10). Two hypotheses may account for these features: (a) stone and

* Personal Communication, 1986, Mr. C. Johnson, Hydraulic Engineer, Coastal Engineering Branch, US Army Engineer Division, North Central. 


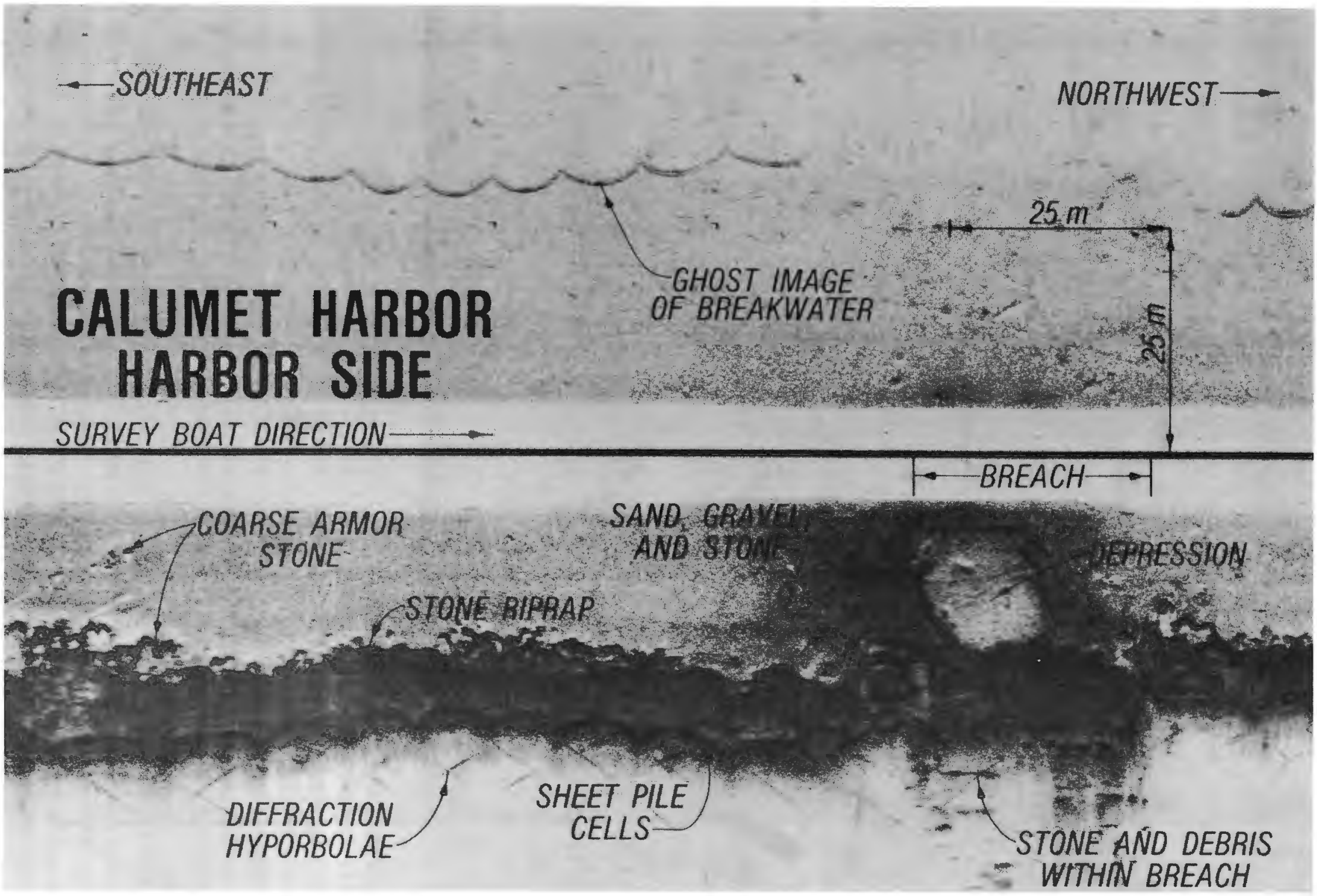

Figure 9. Harbor side, Section C, Calumet Harbor breakwater 


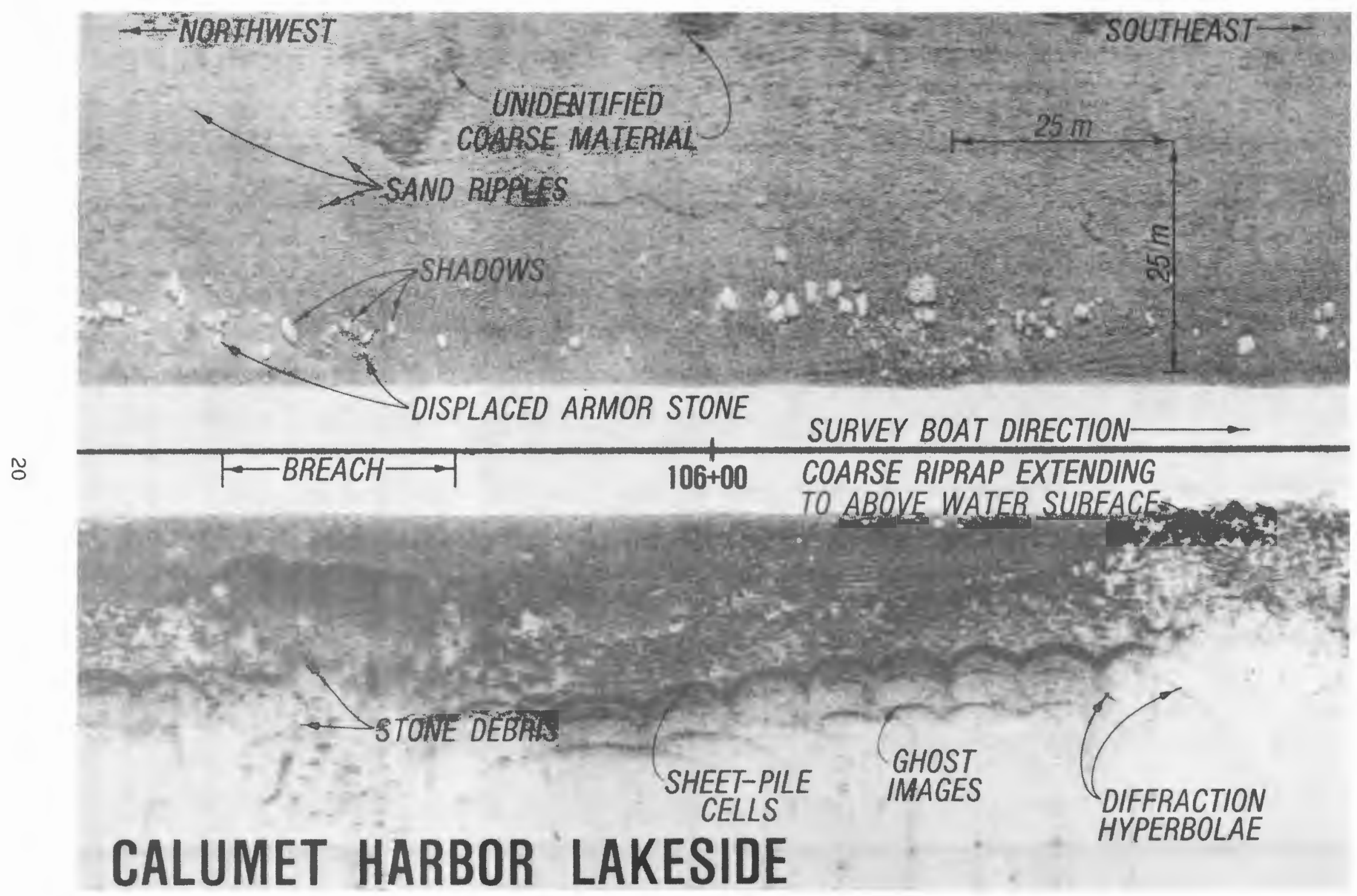

Figure 10. Lakeside, Section C, Calumet Harbor breakwater 
rubble deposited during construction and (b) outcrops of hard limestone. These ovals are of much lower relief than the displaced stones described above and are volumetrically large; therefore, the second hypothesis seens reasonable. A definitive answer requires grab samples or diver inspection.

24. Side-scan sonar records show that most of the breakwater cells and the riprap toe along the lakeside of section $C$ are in good condition. From the north end of Section C to sta $62+00$, coarse riprap extends to above the water surface and masks the underlying steel cells. Along the rest of the structure, the riprap is lower but is continuous and at least 2 to $3 \mathrm{~m}$ wide (Table 3). Since coarse debris prevents imaging within the breach (Figure 10), the condition of that section could not be determined. 


\section{PART IV: DATA ANALYSIS FOR BURNS HARBOR}

26. Burns Harbor Waterway is located on the southern shore of Lake Michigan in Porter County, Indiana, 30 miles southeast of Chicago. The sidescan sonar survey at this location was conducted on 25 September 1986 (Figure 11). The breakwater, which was constructed between 1967 and 1970, is a two-layer rubble-mound design using 10- to 16-ton limestone blocks (Figure 12) (Krampitz 1985). Soll borings indicated that about $3 \mathrm{~m}$ of soft clay was underlain by much harder clay, and, before construction, the soft clay was to have been excavated and replaced with a sand mat. A 1978 plan indicates that the sand mat was supposed to extend at least $10 \mathrm{~m}$ beyond the toe of the structure (Krampitz 1985). The excavated clay was discarded onto the lake bed about 50 to $100 \mathrm{~m}$ from the toe in 15-m water depths.

\section{Harbor Side}

27. The most signiflcant finding of the harbor-side sonar surveys is that the bottom consists of featureless, low-reflectivity clay, and that the clay extends to the very base of the breakwater. In recent years, extra armor stone has been added to the lakeside and harbor side of the structure to repair sections that have settled, but unless the sand mat extended only a slight distance beyond the toe of the original structure, it is unlikely that enough new stone has been added to obscure the clay-sand interface. Figure 13 shows the landward end of the breakwater where it joins Midwest Steel Corporation's steel bulkhead dock. Occasional isolated armor stones can be seen on the harbor floor a few meters from the toe of the breakwater. The breakwater itself, from harbor floor to water surface, is 15 to $20 \mathrm{~m}$ wide. Figure 14 depicts the end of the breakwater near the mouth of Burns Harbor. Dramatic scars on the harbor floor result from ships dragging anchor as they slow and turn into the harbor. Along the base of the structure, the harbor floor continues to be featureless and uniform with the exception of occasional isolated armor stones.

\section{Lakeside}

28. The lakeside survey also provided no evidence of a sand mat 


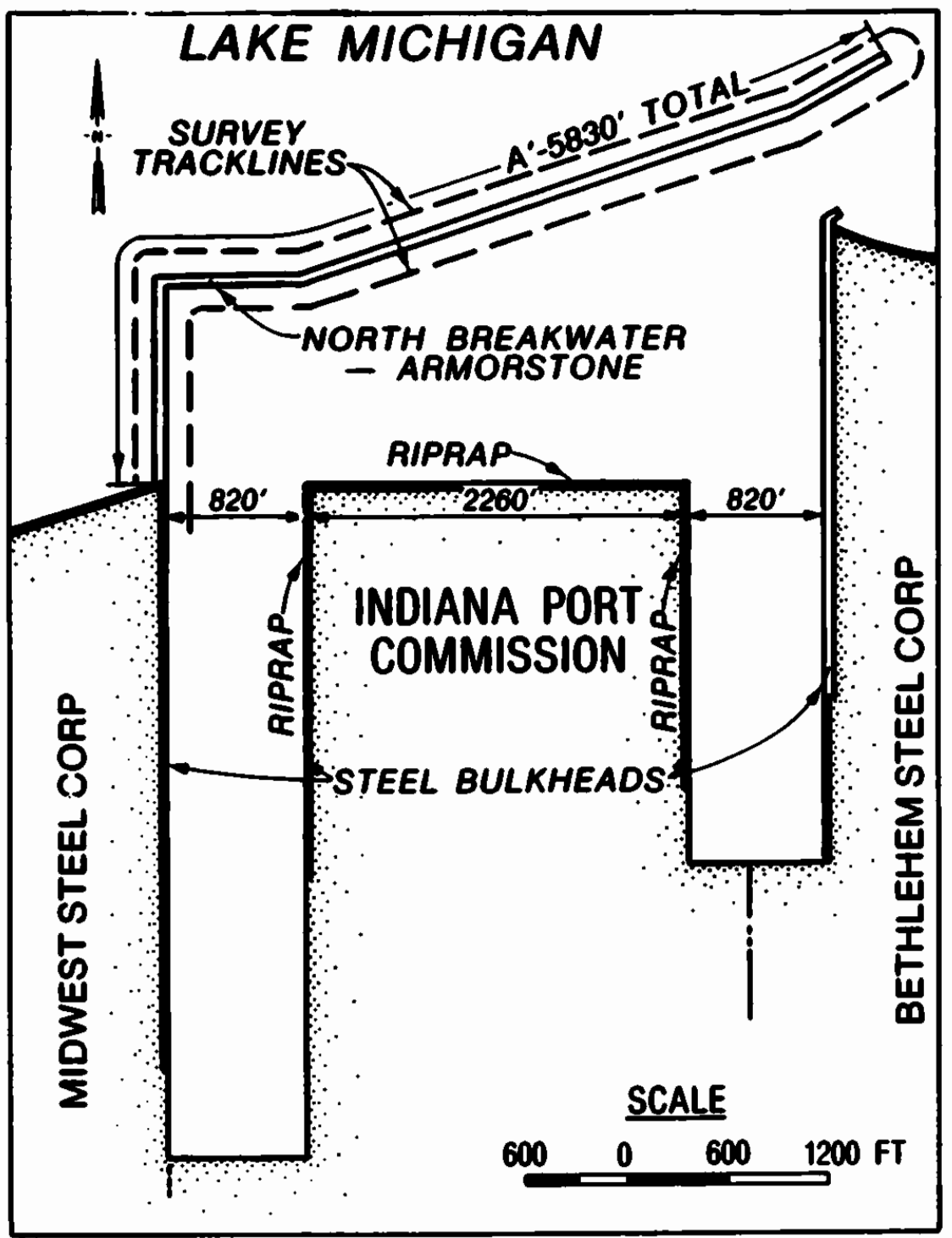

Figure 11. Burns Harbor Waterway, Indiana

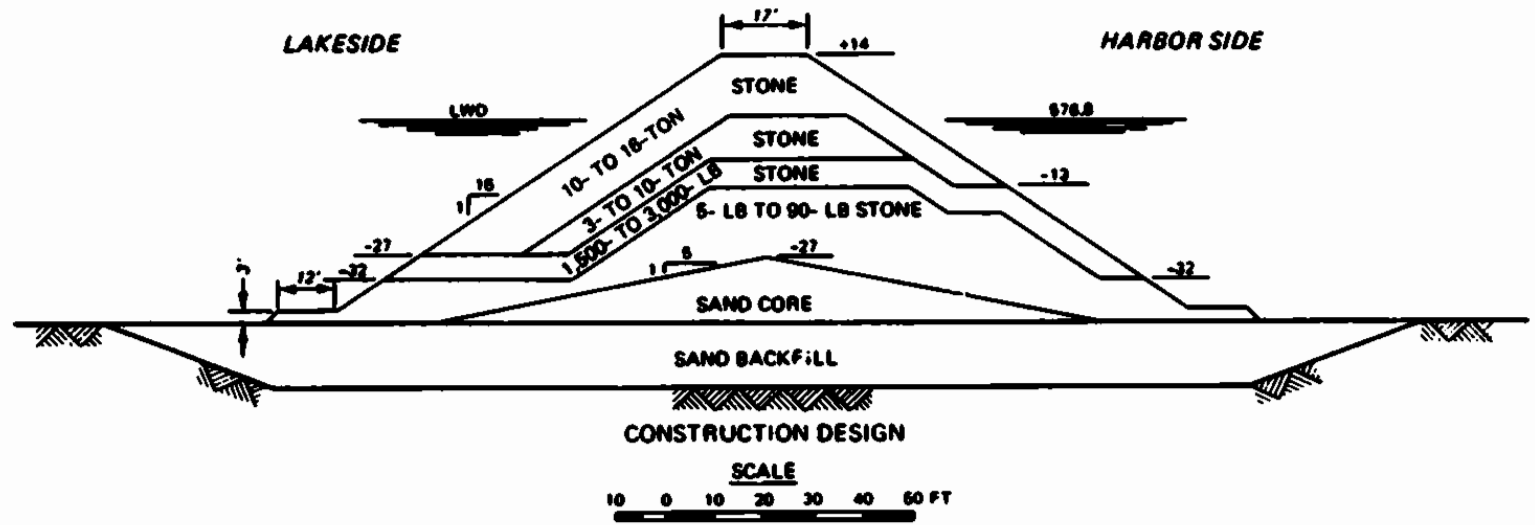

Figure 12. Two-layer rubble-mound breakwater design using 10- to 16-ton limestone blocks 


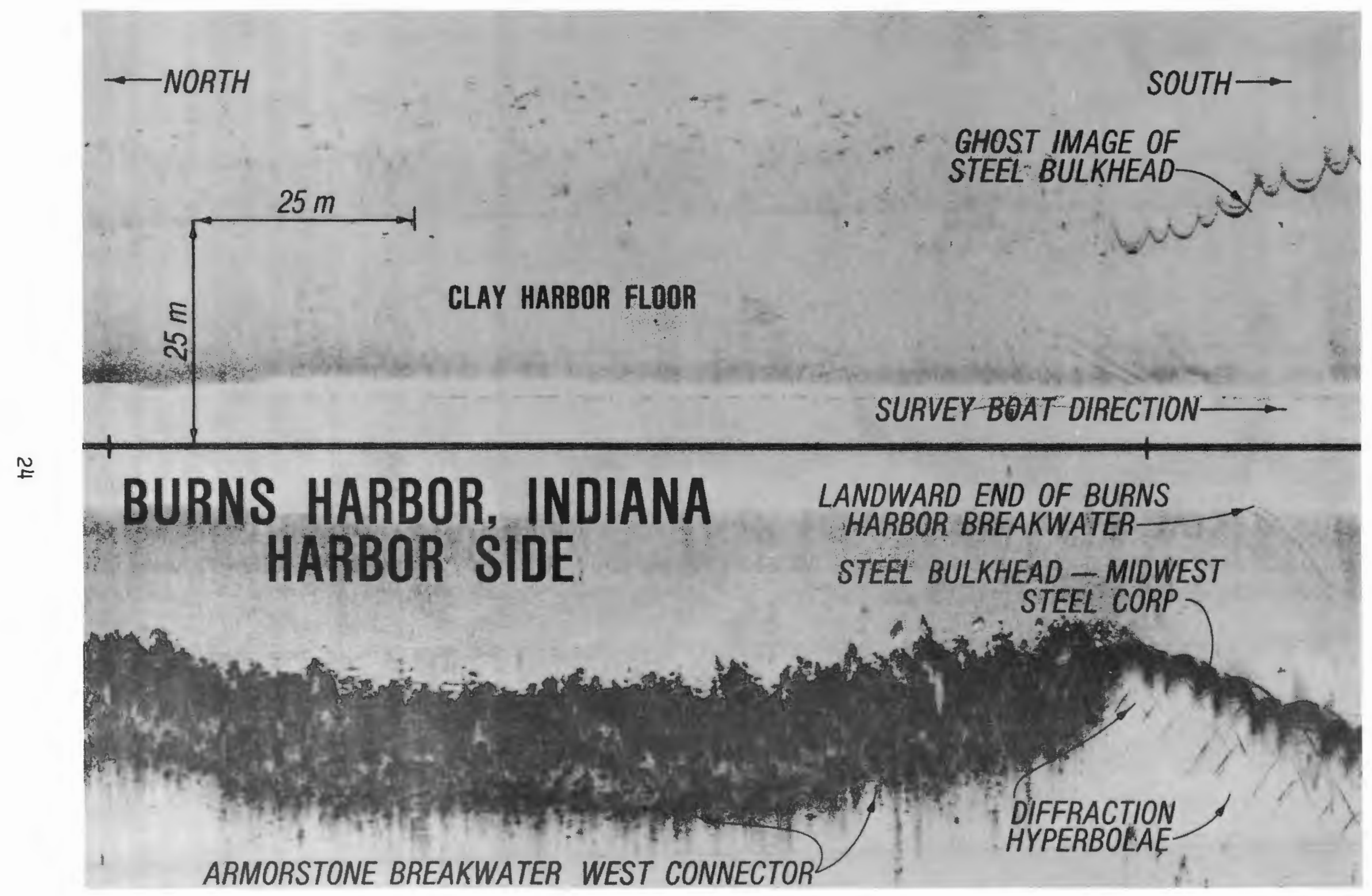

Figure 13. Harbor side, Burns Harbor, landward end 


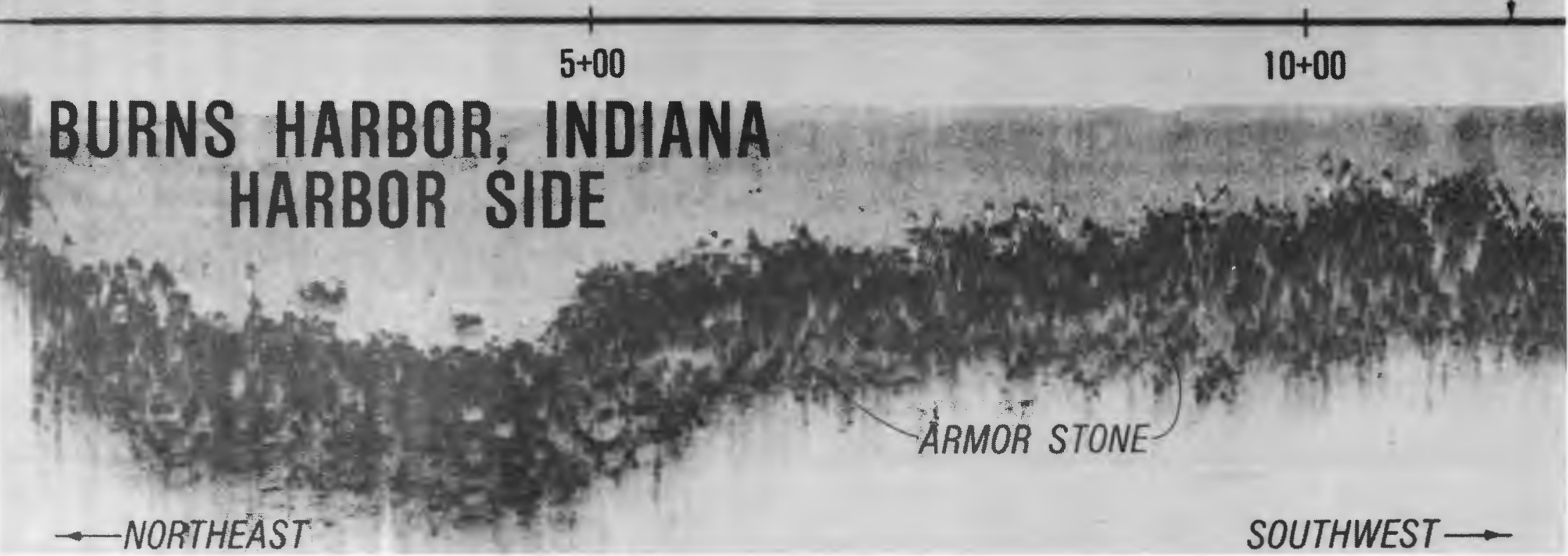

Figure 14. Harbor side, Burns Harbor, end near harbor mouth 
extending beyond the base of the breakwater (Figures 15 and 16). Patches of rippled sand ten or more metres from the base of the structure, as at Calumet Harbor, are belleved to be veneers of sand moved by wave and current action over an essentially clayey lake floor. Many individual armor blocks litter the lake floor. Between sta 1+00 and 5+00, some of the stones along the toe appear to be partly buried. Toe instability may have caused settling or, as an alternative, soft sediments may have accumulated along the toe and covered some of the blocks along with any visible evidence of the sand mat. Although this latter hypothesis is reasonable for the lakeside of the breakwater, the harbor side experiences lower wave energy, and it is unlikely that enough sediment has been available to uniformly cover the sand mat along the entire length of the structure. Suspended sediment is not considered to be a significant factor in Burns Harbor.

29. Large, irregular, oval patches with blocky appearance, high reflectivity, and relief of up to $3 \mathrm{~m}$ probably represent dredged disposal material deposited during breakwater construction in the 1960's (Figures 15 and 16). Grab samples and diver inspections during the summer of 1986 revealed that the piles are composed of gravel and small stone held together with a clay binder. The volume of the dredged materlal is much less than the volume that presumably was excavated for the foundation of the breakwater, although soft clay and sand have undoubtedly been washed away over the last 20 years. Nevertheless, the areal extent of the remaining piles indicates that a large volume of hard solls must have originally been removed from the site of the breakwater, and this finding appears to conflict with reports that soft clay was excavated (Krampitz 1985). 


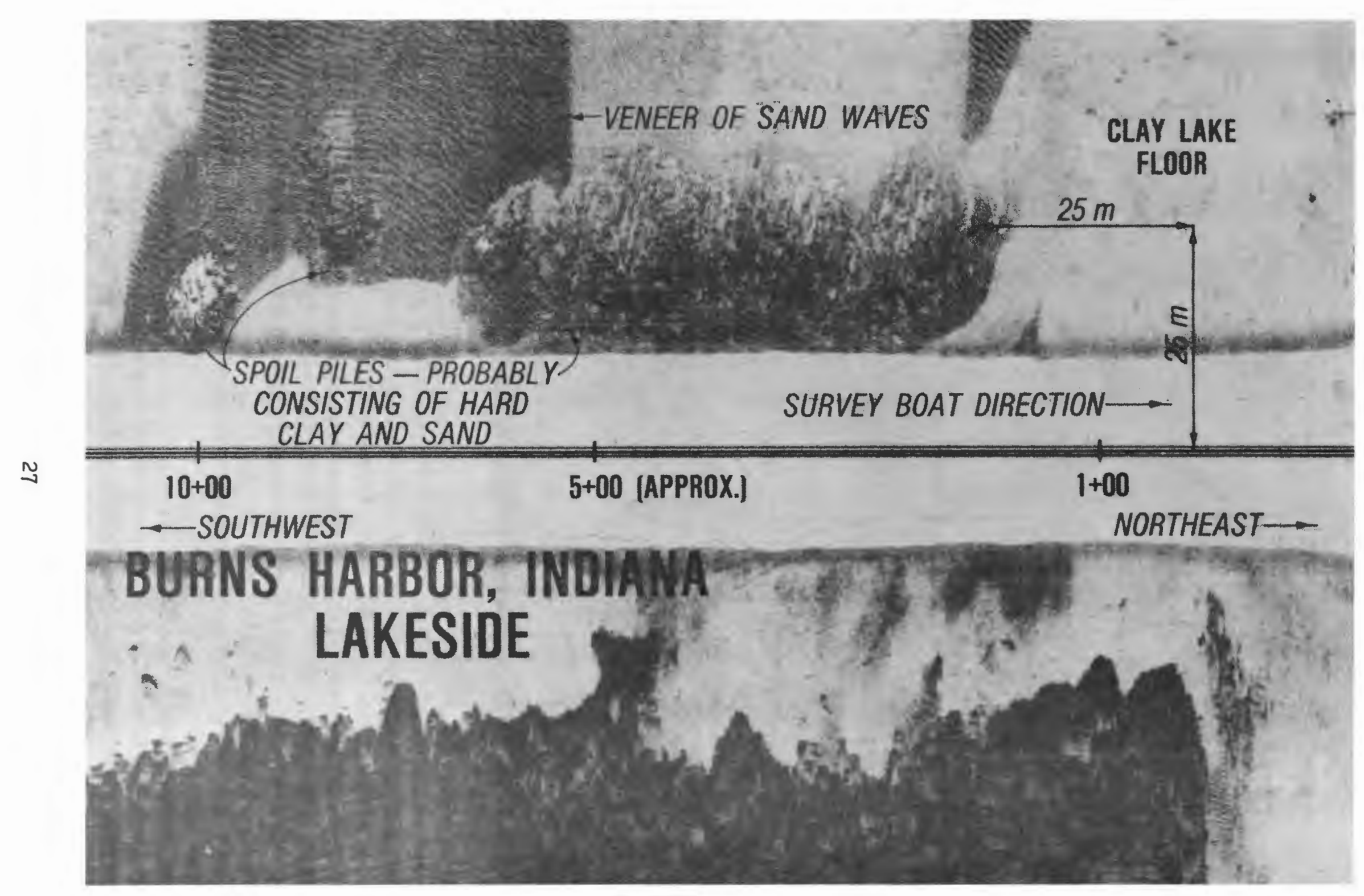

Figure 15. Lakeside, Burns Harbor, northeast end 


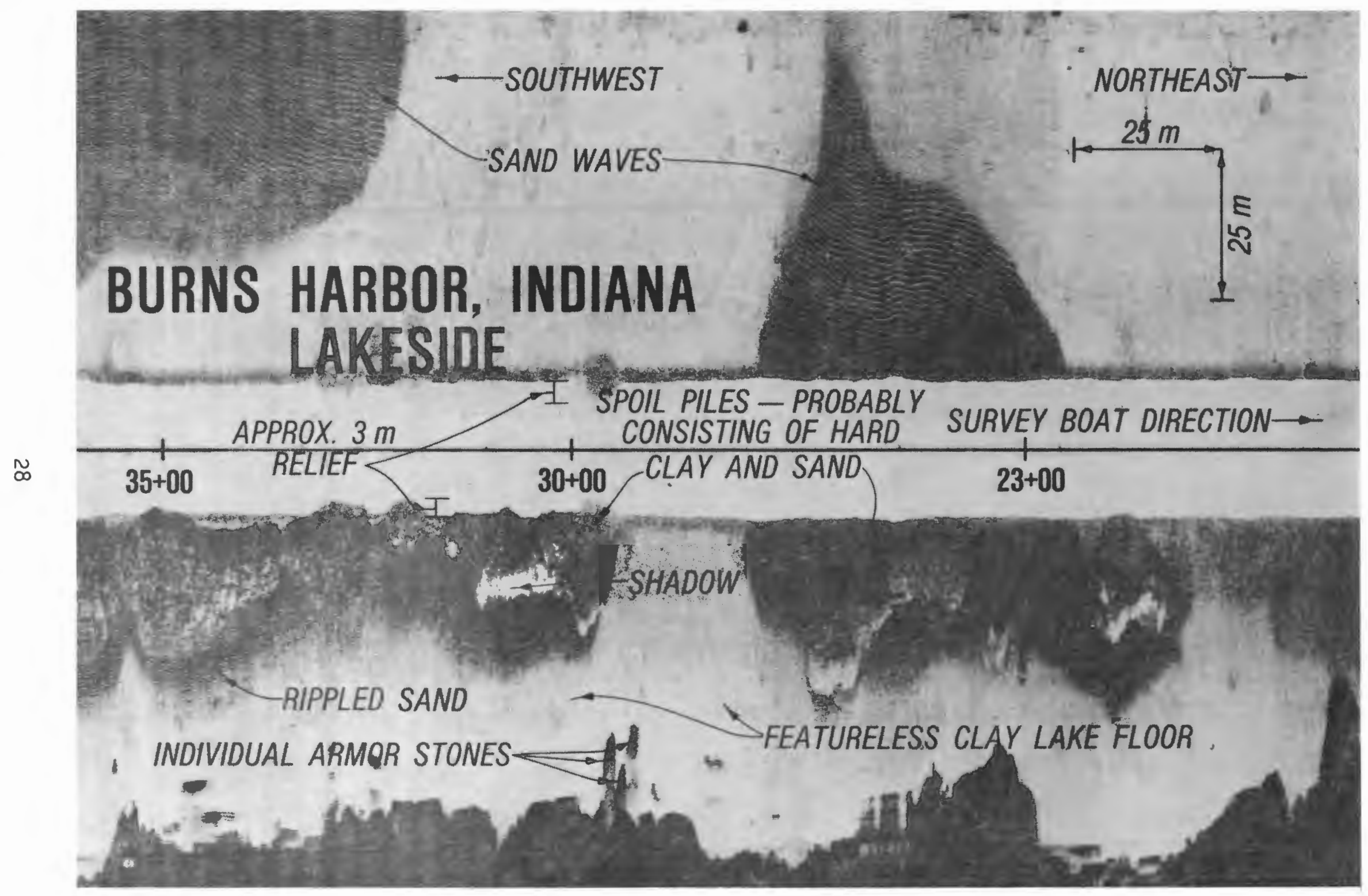

Figure 16. Lakeside, Burns Harbor, end near harbor mouth 
30. A summary of side-scan sonar results at Calumet Harbor is as follows.

a. Many of the cribs in Section A of the Calumet Harbor breakwater appear to have been displaced, particularly on the lakeside.

b. Many of the cribs in Section B also have tilted or settled. Reflections from behind the harbor side of the breakwater suggest that there are gaps in the wall and voids within the structure. Fan-shaped deposits of coarse rubble on the harbor floor are hypothesized to be cones of debris that have flowed out of damaged cribs.

c. Stone toe protection extends continuously along the lakeside of Section $A$. On the harbor side, it is ragged and discontinuous.

d. Riprap toe extends continuously along the lakeside of Section $B$. On the harbor side, the riprap is irregular and appears to be missing in some areas.

e. The Section C sheet-pile cells appear to be in essentially good condition except for the area near the massive failure which occurred in the 1984 storm. Because of the intense signal return from the vertical steel walls, small fractures may be masked or unresolved.

f. The riprap along the lakeside of Section $C$ is continuous and in overall good condition. Large armor stones, or possibly former capstones, are scattered on the lake floor up to $35 \mathrm{~m}$ offshore. The reason for the distribution of this debris is unknown.

31. At Burns Harbor side-scan sonar results revealed the following:

a. There is no evidence from the sonographs that a sand mat extends beyond the base of the Burns Harbor breakwater. Sections of the toe may be settling into the clayey lake floor. Dredged material mounds consist of gravel and stone with a clay binder, presumably excavated from the foundation during breakwater construction. It has not been possible to determine what material was used to replace the excavated soils.

b. Occasional isolated armor stones can be seen on the lake and harbor floor near the toe of the breakwater. These may have been displaced during storms and may account for the need to repair and add new stone to the structure in recent years. 
Belderson, R. H., Kenyon, N. H., Stride, A. H., and Stubbs, A. R. 1972. Sonographs on the Sea Floor, Elsevier Publishing Company, Amsterdam.

Clausner, J. E., and Pope, J. In preparation. "Side-scan Sonar Applications for Evaluating Coastal Structures." Technical Report, US Army Engineer Waterways Experiment Station, Coastal Engineering Research Center, Vicksburg, Miss.

Fleming, B. W. 1976. "Side-scan Sonar: A Practical Guide," International Hydrographic Review, Vol 53, No. 1, pp 65-92.

Krampitz, H. 1985. "Monitoring Completed Coastal Projects, Burns Waterway Harbor, IN," Proceedings of the 42nd Meeting of the Coastal Engineering Research Board," Chicago, IIlinois, US Army Engineer Waterways Experiment Station, Vicksburg, Miss., pp 204-208.

Leenhardt, 0. 1974. "Side Scanning Sonar - A Theoretical Study," International Hydrographic Review, Vol 51, No. 1, pp 61-80.

Mazel, C. 1985. Side-scan Sonar Training Manual, Klein Associates, Inc., Salem, N. H.

Patterson, D. R., and Pope, J. 1983. "Coastal Applications of Side-scan Sonar," Proceedings of Coastal Structures '83, American Society of Civil Engineers, New York, pp 902-910.

Pope, J. 1985, "Side-scan Sonar of Balley's Dam, Red River, Alexandria, Louisiana," Miscellaneous Paper CERC-85-9, US Army Engineer Waterways Experiment Station, Vicksburg, Miss.

US Engineer District, Chicago. 1985. "Reconnaissance Report, Breakwater Rehabilitation, Calumet Harbor, Illinols," Chicago, Ill.

Will lams, S. J. 1982. "Use of High Resolution Seismic Reflection and Sidescan Sonar Equipment for Offshore Surveys," Coastal Engineering Technical Aid 82-5, US Army Engineer Waterways Experiment Station, Vicksburg, Miss. 
Condition of Stone Riprap, Harbor Side, Section B

Calumet Harbor Breakwater

\begin{tabular}{|c|c|c|}
\hline Location & $\begin{array}{l}\text { Approximate } \\
\text { width, m }\end{array}$ & Condition \\
\hline Section A to $19+00$ & $5-10$ & $\begin{array}{l}\text { Discontinuous, with occasional } \\
\text { ragged patches of stone } 15 \mathrm{~m} \text { from } \\
\text { breakwater. }\end{array}$ \\
\hline $19+00$ to $27+00$ & $4-5$ & $\begin{array}{l}\text { Very coarse material characterized } \\
\text { by linear reflections. }\end{array}$ \\
\hline $27+00$ to $34+00$ & $3-5$ & Continuous, finer sized stone. \\
\hline $33+00$ & 12 & $\begin{array}{l}\text { Recently deposited coarse armor } \\
\text { stone; extends from harbor } \\
\text { floor to above water. }\end{array}$ \\
\hline $34+00$ to $36+00$ & $4-5$ & $\begin{array}{l}\text { Coarse material with linear } \\
\text { reflections. }\end{array}$ \\
\hline $36+00$ to $38+00$ & $3-5$ & Continuous, finer size stone. \\
\hline Approximately $38+00$ & & No toe protection. \\
\hline $38+00$ to bend & $2-3$ & $\begin{array}{l}\text { Coarse material with linear } \\
\text { reflections. }\end{array}$ \\
\hline At bend & $5-10$ & Irregular patch of finer stone. \\
\hline Bend to $48+00$ & $4-6$ & $\begin{array}{l}\text { Discontinuous, mixed fine, and } \\
\text { very coarse stone. Separate } \\
\text { patches of fine stone occur } 15 \mathrm{~m} \\
\text { from breakwater. }\end{array}$ \\
\hline $48+00$ to $57+00$ & $5-6$ & $\begin{array}{l}\text { Continuous fine stone with } \\
\text { occasional debris cones extending } \\
\text { up to } 14 \mathrm{~m} \text { from breakwater. }\end{array}$ \\
\hline $57+00$ to $62+00$ & & $\begin{array}{l}\text { No apparent toe protection. Discon- } \\
\text { tinuous, highly reflective patches } \\
\text { near base may be sand on } \\
\text { harbor floor toe protection. }\end{array}$ \\
\hline $62+00$ to $65+00$ & $2-3$ & Medium to coarse stone. \\
\hline $65+00$ to end & $12-15$ & Coarse armor stone. \\
\hline
\end{tabular}


Table 2

Condition of Stone Rlprap, Harbor Side, Section C

Calumet Harbor Breakwater

\begin{tabular}{|c|c|c|}
\hline Location & $\begin{array}{l}\text { Approximate } \\
\text { width, } m \\
\end{array}$ & Condition \\
\hline North end to $62+00$ & 15 & $\begin{array}{l}\text { Very coarse stone, extends to above } \\
\text { water surface. }\end{array}$ \\
\hline $62+00$ to $79+00$ & $5-6$ & $\begin{array}{l}\text { Fine stone, continuous, good } \\
\text { condition. }\end{array}$ \\
\hline $79+00$ to $96+00$ & $7-8$ & $\begin{array}{l}\text { Coarser stone, continuous. } \\
\text { Occasional individual or clusters of } \\
\text { stone scattered on harbor floor } \\
\text { near toe. }\end{array}$ \\
\hline $96+00$ to $104+00$ & $5-6$ & Fine stone, continuous. \\
\hline $\begin{array}{l}\text { Breach In failed } \\
\text { cells }\end{array}$ & & $\begin{array}{l}\text { Coarse stone deposited as temporary } \\
\text { repair. }\end{array}$ \\
\hline $105+00$ to $110+00$ & $5-6$ & Fine stone, continuous. \\
\hline $109+00$ & 10 & Patch of coarse stone. \\
\hline $\begin{array}{l}110+00 \text { to south } \\
\text { end }\end{array}$ & $8-10$ & Medium to coarse stone. \\
\hline
\end{tabular}


Table 3

Condition of Stone Riprap, Lakeside, Section C

Calunet Harbor Breakwater

\begin{tabular}{|c|c|c|}
\hline Location & $\begin{array}{l}\text { Approximate } \\
\text { width, m }\end{array}$ & Condition \\
\hline North end to $62+00$ & $12-15$ & $\begin{array}{l}\text { Very coarse stone, extends to } \\
\text { above water surface. }\end{array}$ \\
\hline $62+00$ to $70+00$ & $4-5$ & $\begin{array}{l}\text { Finer size stone, occasional } \\
\text { deposits of coarser material. }\end{array}$ \\
\hline $70+00$ to $73+00$ & $2-3$ & $\begin{array}{l}\text { Intermittent fine stone, very narrow } \\
\text { or possibly displaced or buried by } \\
\text { sand in areas. }\end{array}$ \\
\hline $73+00$ to gap at & $4-5$ & Continuous fine stone riprap approx. \\
\hline $79+00$ Gap to $96+00$ & $7-10$ & $\begin{array}{l}\text { Irregular width but continuous } \\
\text { coarse riprap. Numerous large } \\
\text { stones up to } 35 \text { offshore. }\end{array}$ \\
\hline $96+00$ to $104+00$ & $5-6$ & Continuous fine to medium stone. \\
\hline $\begin{array}{l}\text { Breach in falled } \\
\text { cells }\end{array}$ & & Stone and wixed debris. \\
\hline $105+00$ to $108+00$ & $5-6$ & Continuous fine to medium stone. \\
\hline $109+00$ & 10 & $\begin{array}{l}\text { Very coarse stone, extends to above } \\
\text { water surface. }\end{array}$ \\
\hline $109+00$ to south end & $6-7$ & Medium to coarse stone. \\
\hline
\end{tabular}


